\title{
Efficacy of the H2-receptor antagonist famotidine on chronic spontaneous urticaria in children
}

\author{
Hideo Takatsuka, Yoshihiko Sakurai, Mutsuzo Takada, Masato Nishino
}

Department of Pediatrics, Nara Prefectural Mimuro Hospital, Ikoma-gun, Japan

Email: ysakurai21@gmail.com

Received 17 October 2012; revised 28 November 2012; accepted 6 December 2012

\begin{abstract}
Urticaria is a common pediatric skin disorder. Histamine H1-receptor antagonists are effective in chronic as well as acute urticaria. When H1-anti-histamines are ineffective, add-on use of H2-receptor antagonists is thought to give better symptom relief. However, there are few reports on the therapeutic efficacy in pediatric patients. We retrospectively reviewed the medical records of pediatric patients with chronic spontaneous urticaria (csU) who met the following criteria. They were consulted our outpatient clinic between April 2010 and March 2012; were unsuccessfully treated with $\mathrm{H1}$ antihistamines; and were treated with add-on H2-receptor antagonist (famotidine). In six patients who met the inclusion criteria (mean age $6.1 \pm 5.1$ years), urticaria activity score was significantly decreased from $4.3 \pm 0.8$ just before administration of famotidine to $1.3 \pm 1.0$ on the first outpatient visit within 4 weeks after the first administration of famotidine $(p<0.0001)$. No adverse effects of famotidine were observed. Although this study has a limitation of small subjects, our results suggest the potential efficacy of add-on use of H2-receptor antagonists and might justify extending the range of application of H2-receptor antagonists to pediatric patients with csU.
\end{abstract}

Keywords: Chronic Spontaneous Urticaria; H2-Receptor Antagonist; Famotidine; Children

\section{INTRODUCTION}

Urticaria is a fairly common skin disorder in children and is characterized by transient, pruritic, variably sized wheals with well-defined borders and central pallor. When urticaria occurs without any trigger, it is classified as spontaneous. In childhood, stimuli such as infection, foods, and medication easily provoke acute urticaria [1]. Although most urticaria in children is inducible and acute, some urticaria are spontaneous and some become chronic. The prevalence of chronic urticaria in children is $0.1 \%-0.3 \%$, whereas that of all forms of pediatric urticaria is around $3.4 \%$ in United Kingdom [2,3]. Greaves et al. described three main subtypes of chronic urticaria: chronic spontaneous urticaria (csU), physical/ inducible urticaria, and urticarial vasculitis [4]. Among these, csU is the most common in children, accounting for $50 \%-60 \%$ of pediatric cases of chronic urticaria, but little data are available [5]. As the aesthetic aspects of csU may significantly impair quality of life, it is not uncommon for pediatric patients with this disorder to suffer from school refusal [6].

Recent guidelines recommend H1-receptor antagonists as first-line treatment for chronic as well as acute urticaria $[7,8]$. In cases where these fail to benefit csU, several step-up management options are suggested, including histamine H2-receptor antagonists, leukotriene-receptor antagonists (LTRA), ciclosporin, dapsone, and anti-immunoglobin E (IgE; omalizumab). Although a recent Cochrane Review could not resolve uncertainty over the role of H2-receptor antagonists in urticaria [9], add-on use of an H2-receptor antagonist with an H1receptor antagonist has been described effective for chronic urticaria resistant to H1-receptor antagonists in adults [10,11].

Regarding recent reviews on pediatric chronic urticaria, one put H2-receptor antagonists collectively in the same category with first- and second-generation H1receptor antagonists as anti-histamines [1], and the other treated them as second-line drugs such as LTRA and ciclosporin [12]. However, these recommendations about the use of H2-receptor antagonists were based on experiences in adult rather than pediatric patients with csU. Little research has evaluated the effectiveness of H2receptor antagonists in pediatric csU.

We report here a retrospective series of six pediatric patients with csU resistant to H1-receptor antagonists who were successfully treated with the $\mathrm{H} 2$-receptor 
antagonist, famotidine, in the past two years.

\section{DESIGN AND METHODS}

\subsection{Patients}

We retrospectively reviewed the medical records of pediatric patients who met the following criteria. They were diagnosed with csU according to the guideline [7,8]; consulted our outpatient clinic between April 2010 and March 2012; were unsuccessfully treated with H1 antihistamines including an alternative $\mathrm{H} 1$ agent and/or dose escalation of the original agent; and were treated with add-on famotidine.

\subsection{Treatment}

In the acute management of urticaria, H1-receptor antagonists irrespective of the generations should be used. Famotidine (Gaster ${ }^{\circledR}$, Astellas Pharma Inc., Tokyo) was chosen as H2-receptor antagonist for pediatric use as it has the advantage of being a powder formulation so that it can easily be taken by pediatric patients orally and the dose readily adjusted for the patient's weight. H1receptor antagonist treatment was continued at the start of famotidine administration. Famotidine was administered orally to each patient twice daily ( $1 \mathrm{mg} / \mathrm{kg} /$ day).

After famotidine treatment was commenced, patients consulted our outpatient clinic at a maximum of 4 -week intervals. Therapeutic efficacy was evaluated using the urticaria activity score (UAS) $[8,13]$.

\subsection{Statistical Analysis}

Data are presented as mean \pm SD. The significance of differences between two groups was determined by Student's t test, with the level of significance set at $\mathrm{p}<$ 0.05 . Analyses were performed using the GraphPad Prism (GraphPad Software, San Diego, CA).

\section{RESULTS}

\subsection{Patient Characteristics}

Six patients (three male, three female) met the inclusion criteria. Table 1 shows their characteristics. Mean age was $6.1 \pm 5.1$ years (range, 1.3 year to 12.9 years). Mean total IgE level was $251.8 \pm 250.3 \mathrm{IU} / \mathrm{mL}$ (range, 8.9 to 630). Thyroid function tests showed no abnormality in any of the patients. None of the patients had symptoms

Table 1. Patient profiles and treatment details.

\begin{tabular}{|c|c|c|c|c|c|c|c|c|}
\hline \multirow{2}{*}{$\begin{array}{l}\text { Patient } \\
\text { No. }\end{array}$} & \multirow{2}{*}{ Sex } & \multirow{2}{*}{$\begin{array}{c}\text { IgE } \\
(\mathrm{IU} / \mathrm{mL})\end{array}$} & \multirow{2}{*}{$\begin{array}{c}\text { Age } \\
\text { at diagnosis } \\
\text { (Months) }\end{array}$} & \multirow{2}{*}{ Acute treatment } & \multirow{2}{*}{ Chronic treatment } & \multicolumn{2}{|c|}{ Urticaria activity score } & \multirow{2}{*}{$\begin{array}{l}\text { Duration from } \\
\text { famotidine } \\
\text { start to cessation } \\
\text { (Month) }\end{array}$} \\
\hline & & & & & & Pre & Post & \\
\hline 1 & $\mathrm{~F}$ & 8.9 & 16 & $\begin{array}{c}\text { ketotifen } \\
\text { cyproheptadine }\end{array}$ & $\begin{array}{c}\text { clemastine }^{*} \\
\text { epinastine } \\
\text { loratadine } \\
\text { betamethasone** }\end{array}$ & 4 & 0 & 3 \\
\hline 2 & $\mathrm{~F}$ & 57.1 & 29 & clemastine $^{*}$ & $\begin{array}{l}\text { clemastine* } \\
\text { epinastine }\end{array}$ & 3 & 0 & 8 \\
\hline 3 & M & 188 & 32 & $\begin{array}{l}\text { clemastine }^{*} \\
\text { ketotifen }\end{array}$ & $\begin{array}{l}\text { clemastine* } \\
\text { ketotifen } \\
\text { epinastine }\end{array}$ & 4 & 2 & 4 \\
\hline 4 & $\mathrm{~F}$ & 138 & 61 & $\begin{array}{l}\text { epinastine } \\
\text { pranlukast }^{\dagger}\end{array}$ & $\begin{array}{l}\text { ketotifen } \\
\text { epinastine } \\
\text { loratadine } \\
\text { pranlukast }^{\dagger}\end{array}$ & 5 & 2 & continued \\
\hline 5 & M & 630 & 145 & $\begin{array}{l}\text { oxatomide* } \\
\text { loratadine }\end{array}$ & $\begin{array}{l}\text { ketotifen } \\
\text { loratadine }\end{array}$ & 5 & 2 & continued \\
\hline 6 & M & 489 & 155 & $\begin{array}{c}\text { loratadine } \\
\text { olopatadine }\end{array}$ & $\begin{array}{l}\text { olopatadine } \\
\text { bepotastine }\end{array}$ & 5 & 2 & 5 \\
\hline
\end{tabular}

Pre: Just before administration of famotidine; Post: On the first outpatient visit within 2 - 4 weeks after the first administration of famotidine; ${ }^{*}$ First generation antihistamines; ${ }^{* *}$ Temporary use of steroids; ${ }^{\dagger}$ The patient had received pranlukast after RS virus infection. 
or signs of underlying disease, including fever, significant malaise, and arthralgia.

\subsection{Treatment}

In the acute management of urticaria, H1-receptor antagonists used included the first-generation H1-antihistamines such as cyproheptadine, clemastine, and oxatomide, and the second-generation agents ketotifen, epinastine, loratadine, and olopatadine. In the chronic phase of urticaria, first-generation as well as second-generation H1-receptor antagonists were used again (Table 1).

The period from diagnosis of csU to the date of first administration of famotidine was $3.2 \pm 4.0$ months (range 2 days to 11 months). UAS was significantly decreased from $4.3 \pm 0.8$ just before administration of famotidine to $1.3 \pm 1.0$ on the first outpatient visit within 2 - 4 weeks after the first administration of famotidine (p $<0.0001$, Figure 1). In two of the six patients, we have not been able to discontinue famotidine as cessation resulted in mild recurrence of urticaria. One of the remaining four patients has taken an H1-antihistamine for allergic rhinitis, but the other three patients have discontinued antihistamines completely. These four patients have shown no wheals in the absence of famotidine after concurrent $\mathrm{H} 1$ - and $\mathrm{H} 2$-antihistamines resolved urticaria. In a single case (\#4), the patient had taken the LTRA pranlukast in both the chronic and acute phases in order to prevent the onset of asthma after respiratory syncytial virus infection $[15,16]$.

No adverse effects due to concurrent administration of famotidine were observed. Furthermore, adverse effects such as drowsiness arising from H1-antihistamines were not enhanced by concurrent administration of famotidine.

\section{DISCUSSION}

Add-on use of famotidine with H1-antihistamines produ-

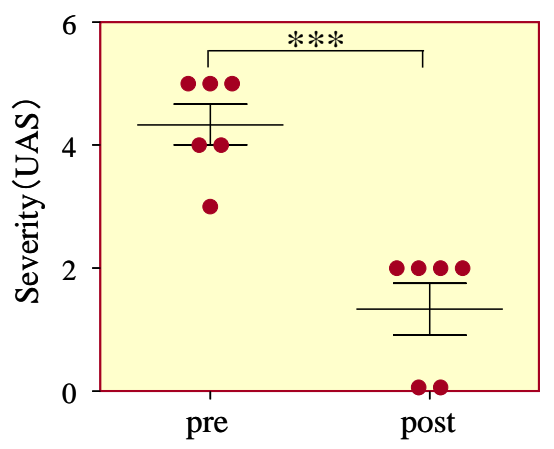

Figure 1. Urticaria activity score just before add-on use of famotidine (pre) and on the first attendance at our clinic 2 - 4 weeks after the first administration of famotidine (post). ${ }^{* * *} \mathrm{p}<0.0001$. ced a favorable outcome in all the present pediatric patients with H1-antihistamine-refractory csU. Pediatric csU often spontaneously resolve, which would make it difficult to properly evaluate the effect of famotidine on csU. In this study, to assess urticaria symptoms correctly, UAS on the first outpatient visit was used. According to the patients' mothers, however, every patient in this study achieved symptomatic relief such as improvement of itch and reduction of both area and number of hives within a few days after the beginning of famotidine administration, which strongly suggest that famotidine produced clinical improvement of csU rather than csU spontaneously resolved.

However, doubt exists regarding the efficacy of H2receptor antagonists in csU. Although stimulation of H1and H2-receptors, both of which are present in skin vessels, induces formation of erythema and wheals, H2receptor stimulation alone does not lead to a warm sensation and itching [14], suggesting that the blockade of H2-receptor may be of little value in the treatment of urticaria. In addition, previous studies on the effect of combined use of H1-receptor antagonists and the H2receptor antagonist cimetidine revealed that cimetidine's inhibitory action on several cytochrome P450 isozymes (such as CYP3A4) interferes with the hepatic metabolism of H1-receptor antagonists such as chlorpheniramine and hydroxyzine [15]. However, as famotidine contains a thiazole ring structure instead of the methylimidazole ring that plays a critical role in cimetidine's inhibitory action on the cytochrome P450 enzyme system, famotidine has no effects on this enzyme system [16]. Therefore, famotidine may exert an effect in csU by unknown mechanisms.

As regarding the $\mathrm{H} 1$ antihistamines used in our patients, sedating H1-receptor antagonists were administered in both acute and chronic phase mainly in the previous clinics. Sedating $\mathrm{H} 1$ antihistamines can be effective and well tolerated by some individuals and use of them at night may help in producing better sleep [12]. Sedating H1-receptor antagonists were likely to be administered to achieve such purposes. However, in our clinic, they have been used less frequently in recent years as recent guidelines recommend against the routine use of the older sedating first-generation antihistamines.

LTRA is recommended as one of step-up management options. In a single case of this study, the LTRA with H1-receptor antagonist had been used but showed little benefit for csU. Of interest was that add-on use of famotidine resulted in a cure of csU in the patient. This is a single case experience and whether famotidine has a greater potency than LTRA should be further explored.

The major limitation of this study was its small sample size. Further studies enrolling a larger number of patients are required to confirm our findings. However, our 
results further support previous findings of the potential efficacy of add-on use of famotidine and might justify extending the range of application of H2-receptor antagonists from adults to pediatric patients with csU. In intractable csU, we often have no other alternative than immunomodulators such as oral steroids and ciclosporin. However, the present results suggest that famotidine could be used as adjunctive treatment before immunomodulating treatment.

\section{REFERENCES}

[1] Zitelli, K.B. and Cordoro, K.M. (2011) Evidence-based evaluation and management of chronic urticaria in children. Pediatric Dermatology, 28, 629-639. doi:10.1111/j.1525-1470.2011.01518.x

[2] Khakoo, G., Sofianou-Katsoulis, A., Perkin, M.R. and Lack, G. (2008) Clinical features and natural history of physical urticaria in children. Pediatric Allergy and Immunology, 19, 363-366. doi:10.1111/j.1399-3038.2007.00667.x

[3] Greaves, M.W. (2000) Chronic urticaria in childhood. Allergy, 55, 309-320. doi:10.1034/j.1398-9995.2000.00116.x

[4] Greaves, M.W. and Tan, K.T. (2007) Chronic urticaria: Recent advances. Clinical Reviews in Allergy \& Immunology, 33, 134-143. doi:10.1007/s12016-007-0038-3

[5] Church, M.K., Weller, K., Stock, P. and Maurer, M. (2011) Chronic spontaneous urticaria in children: Itching for insight. Pediatric Allergy and Immunology, 22, 1-8. doi:10.1111/j.1399-3038.2010.01120.X

[6] Powell, R.J., Du Toit, G.L., Siddique, N., Leech, S.C., Dixon, T.A., Clark, A.T., et al. (2007) BSACI guidelines for the management of chronic urticaria and angio-oedema. Clinical \& Experimental Allergy, 37, 631-650. doi:10.1111/j.1365-2222.2007.02678.x

[7] Hide, M., Morita, E., Furukawa, F., Shiohara, T., Soma, Y., Kameyoshi, Y., et al. (2011) Practice guidelines for urticaria. The Japanese Journal of Dermatology, 121, 1339-1388.
[8] Zuberbier, T., Asero, R., Bindslev-Jensen, C., Walter Canonica, G., Church, M.K., Gimenez-Arnau, A., et al. (2009) EAACI/GA(2)LEN/EDF/WAO guideline: Definition, classification and diagnosis of urticaria. Allergy, 64, 1417-1426. doi:10.1111/j.1398-9995.2009.02179.x

[9] Fedorowicz, Z., van Zuuren, E.J. and Hu, N. (2012) Histamine H2-receptor antagonists for urticaria. Cochrane Database of Systematic Reviews, 3, Article ID: CD008596.

[10] Lee, E.E. and Maibach, H.I. (2001) Treatment of urticaria. An evidence-based evaluation of antihistamines. American Journal of Clinical Dermatology, 2, 27-32. doi:10.2165/00128071-200102010-00005

[11] Fernando, S. and Broadfoot, A. (2010) Chronic urticariaAssessment and treatment. Australian Family Physician, 39, 135-138.

[12] Grattan, C.E. and Humphreys, F. (2007) Guidelines for evaluation and management of urticaria in adults and children. British Journal of Dermatology, 157, 1116-1123. doi:10.1111/j.1365-2133.2007.08283.x

[13] Erbagci, Z. (2002) The leukotriene receptor antagonist montelukast in the treatment of chronic idiopathic urticaria: A single-blind, placebo-controlled, crossover clinical study. The Journal of Allergy and Clinical Immunology, 110, 484-488. doi:10.1067/mai.2002.126676

[14] Black, A. and Greaves, M. (2002) Antihistamines in urticaria and angioedema. In: Simons, F. and Simons, R. Eds., Histamine and H1-Antihistamines in Allergic Disease, 2nd Edition, Marcel Dekker Inc., New York.

[15] Kosoglou, T., Salfi, M., Lim, J.M., Batra, V.K., Cayen, M.N. and Affrime, M.B. (2000) Evaluation of the pharmacokinetics and electrocardiographic pharmacodynamics of loratadine with concomitant administration of ketoconazole or cimetidine. British Journal of Clinical Pharmacology, 50, 581-589. doi:10.1046/j.1365-2125.2000.00290.x

[16] Pasanen, M., Arvela, P., Pelkonen, O., Sotaniemi, E. and Klotz, U. (1986) Effect of five structurally diverse H2receptor antagonists on drug metabolism. Biochemical Pharmacology, 35, 4457-4461. doi:10.1016/0006-2952(86)90763-X 